\title{
A NEW COCKROACH GENUS (GURNEYA) PREVIOUSLY CONFUSED WITH PINACONOTA (BLABERIDAE: EPILAMPRINAE).*
}

\author{
By Louis M. Roth \\ Pioneering Research Laboratory \\ U.S. Army Natick Laboratories \\ Natick, Massachusetts or 760
}

Princis (1967) listed 2 species of Pinaconota, viz. bifasciata (Saussure) and obliqua (Walker). Ischnoptera (?) sicca Walker was synonymized by Kirby (1904) with bifasciata, but I ( 1973a) showed that Kirby was incorrect in his interpretation of the species and placed sicca in the new genus Alphelixia. The male genitalia and other morphological characters of obliqua indicate that this species is not a Pinaconota and a new genus is erected for it (see below).

In describing Pinaconota, Saussure (1895) simply stated that the hind metatarsi were very short, with a fringe of long hairs, and a large apical pulvillus. Shelford's (I9IO) characterization of the genus is as follows: Form depressed. Pronotum trapezoidal, anteriorly and posteriorly sub-truncate, deeply punctate. Scutellum exposed. Tegmina and wings fully developed, extending beyond the apex of the abdomen. Femora moderately spined beneath. Tarsi very short, fimbriate, and entirely unarmed beneath; posterior metatarsus equal in length to the two succeeding joints, its pulvillus large. Arolia very large. In this generic description, Shelford was apparently influenced by his belief that Ischnoptera (?) obliqua Walker was a Pinaconota.

Pinaconota can be recharacterized as follows:

Pinaconota Saussure

Type-species: Blatta bifasciata Sauss., Monotypy ( 1895, p. 337)

Both sexes with tegmina and wings abbreviated, or extending slightly beyond the end of the abdomen. Ventro-anterior margin of front femur with 2 or more, small, heavy spines, followed by a row of small uniformly spaced slender setae, terminating in a large distal spine; ventro-anterior margins of mid and hind femora with 2 or 3 widely spaced spines, with or without distal spines; hind metatarsus short with 2 rows of fine ventral setae; pulvilli and arolia very

\footnotetext{
*Manuscript received by the editor January 15, 1974.
} 


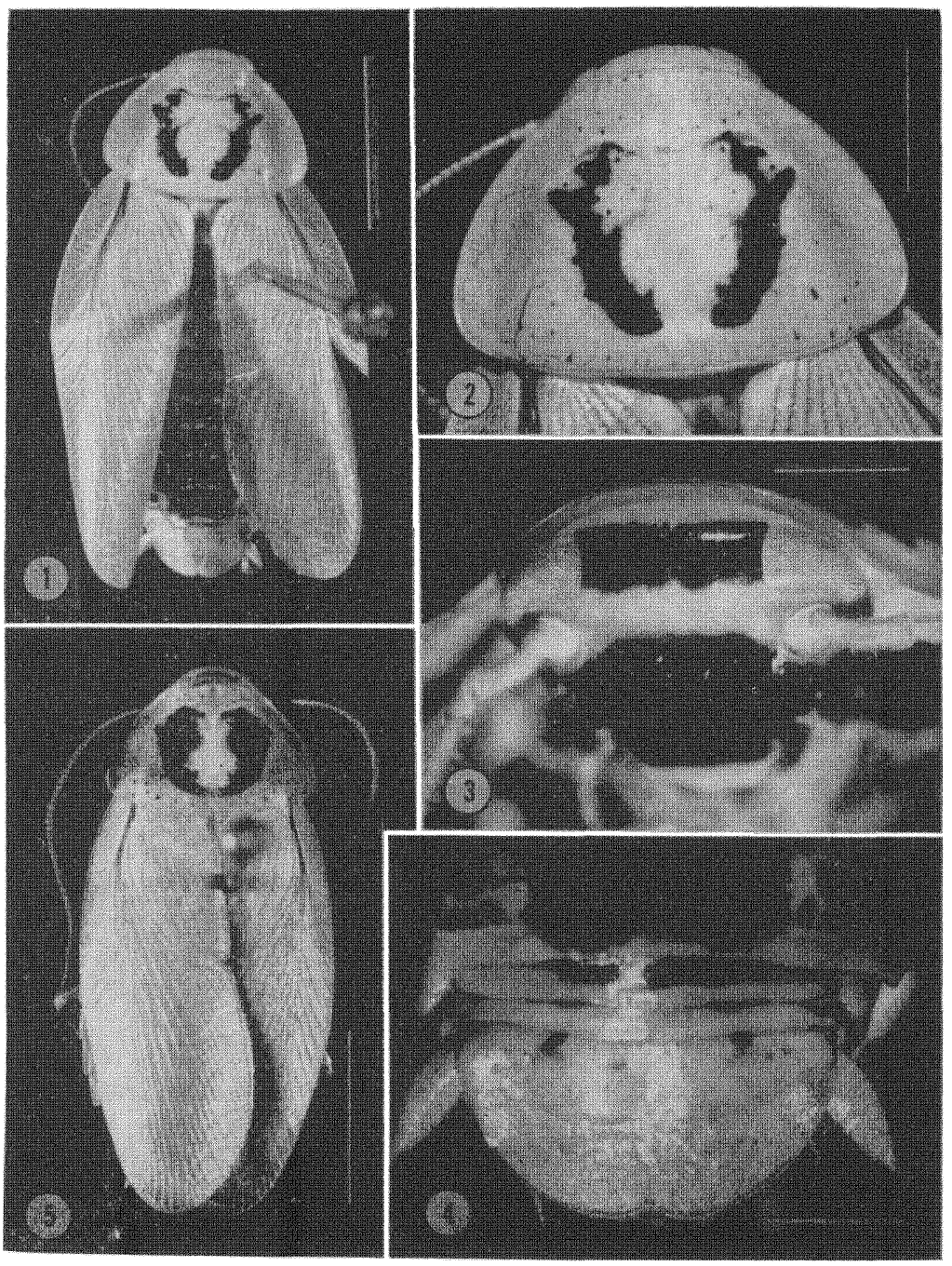

Figs. 1-5. Pinaconota bifasciata. 1-4. Male, from Brazil. 2. Pronotum. 3. Head. 4. Terminal abdominal segments (dorsal). 5. Male from S. Cath., Brazil. (scale: figs. 1 and $5=5 \mathrm{~mm}$; fig. $2=2 \mathrm{~mm}$; figs. 3 and $4=$ $1 \mathrm{~mm})$. 
large. Supra-anal plate rounded with a mesal indentation. Cerci short, reaching to about the hind margin of supra-anal plate. Subgenital plate $\left(\sigma^{\pi}\right)$ asymmetrical, broadly, but weakly concave on right side; styli about equal. Male genitalia: L2d a small irregularly shaped sclerotized plate separated from L2vm; prepuce densely spicular in part, with or without large spines on the free margin (Figs. 15, I 7, 20, 23, 29, 30; see Fig. 29 for naming of parts), a light sclerotized plate present ventral to the $\mathrm{L}_{2} \mathrm{vm}$. The membrane lying above the L2vm may have a number of small spines (Fig. I5) but in the flattened $\mathrm{KOH}$ preparations are not shown in their normal position (Figs. 20, 23). R2 unique in having a finger-like basal projection directed toward the inner curved margin of the hook (Figs. I6, I8, 21, 31). Right paraproct considerably more developed than the left (Figs. I3, 27-28).

The presence of large spines on the prepuce is, as far as I know, unique for a member of the Epilamprinae, and has only been found in the Blaberinae. However, in that subfamily the spines usually closely surround the L2d (Roth, 1970a). Because of the unusual genital structures, I place Pinaconota in the tribe Pinaconotini.

The following is a redescription of Pinaconota bifasciata supplementing that of Saussure:

\section{Pinaconota bifasciata (Saussure)}

(Figs. I-23)

Blatta bifasciata Saussure (Rev. Mag. Zool., 1862, p. 165; Mém. Hist. nat. Mexique, Genève, 1864, 4, p. 98, ô $\$$ ).

Phyllodromia bifasciata (Saussure) (Brunner, Nouv. Syst. Blatt. Vienne, 1865, p. 94).

Epilampra bifasciata (Saussure) (Miss. scient. Mexique, Rech. zool. Paris, 1870 , pt. 6, p. 84, pl. 2. Figs. 44, 44A).

Pinaconota bifasciata (Saussure) (Rev. suisse Zool. 1895, 3, p. 337).

$0^{\pi}$. (Figs. I, 5, 7). Face smooth with scattered small setae, vertex exposed. Pronotum semi-circular, somewhat flattened but with sides slightly deflexed, hind margin subtruncate or weakly curved. Tegmina abbreviated, reaching to about the middle of fourth tergite (Fig. 7) or fully developed extending beyond the end of the abdomen (Figs. I, 5), rounded apically; plical furrow strongly arched, the furrows from both tegmina meeting to form a semi-ovoid anal field, anal veins of left tegmen shallowly punctate; veins of right tegmen punctate only in that portion not covered by the overlapping left tegmen; many veins on other parts of the tegmina also shallowly punctate. Abdomen broad. Supra-anal plate rounded, mesally indented. Cerci not extending beyond hind margin of supra- 

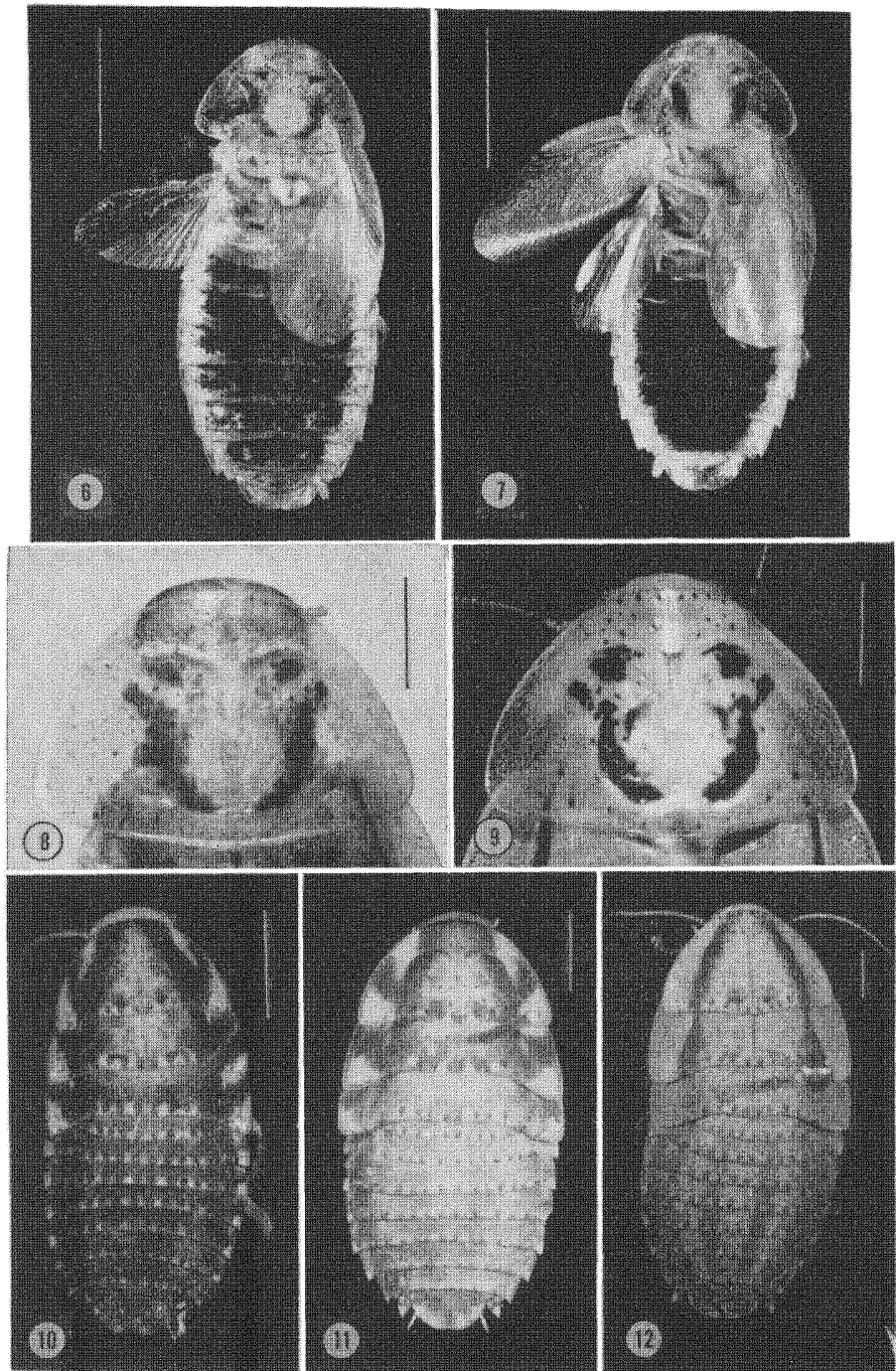

Figs. 6-12. Pinaconota bifasciatia. 6. Brachypterous female. 7. Brachypterous male. 8. Pronotum of female shown in fig. 6. (both $\hat{\delta}$ and $q$ from Ilha das Alcatrazes, S. Paulo, Brazil.) 9. Pronotum of macropterous o taken at quarantine on a plane in Miami, Florida (with bromeliads), Jan. 20, 1972. 10-12. Three nymphs: 10 and 12. From Brazil, in plane at San Francisco, Nov. 17, 1970 (with bromeliads). 11. From Brazil, at Hoboken, Oct. 30, 1940 (with orchids). (scale: figs. 6-7 $=5 \mathrm{~mm}$; figs. $8-12=2 \mathrm{~mm}$ ). 
anal plate (Figs. 4, I3), flattened dorsally with few scattered setae, somewhat convex ventrally covered with many short and a few long setae. Subgenital plate asymmetrical, apex of hind margin subacute, the right side shallowly concave, styli about equal, not extending beyond the apex of the plate (Fig. 14). Leg armament as described for genus: Antero-ventral margin of front femur with 2-6 small but stout spines followed by a row of very small setae. Pulvilli very large, apical on the metatarsi, and covering practically the entire ventral surfaces of the other tarsal segments; arolia very large. Genital phallomeres shown in figures 15-23: L2d an irregularly shaped sclerotized plate separated from L2vm (Figs. I5, I7, $20,23)$; preputial membrane modified into a densely spicular area with 3 or more large spines; a pale sclerotized plate continues beyond the dense spicular area (Fig. I5) ; the membrane above L2vm with many small spines; $\mathrm{LI}_{\mathrm{I}}$ with a deep, heavily sclerotized, upcurved cleft, the upper lobe smaller than the lower lobe which lacks setae (Figs. 19, 22). R2 strongly curved, the apex partly membranous, enlarged, a large finger-like projection extending from the base toward the inner margin of the curved portion (Figs. I6, I8, 2I).

Measurements $(\mathrm{mm})$ : Total length, I5-I6.5; pronotum length $X$ width, 4.I-4.2 $\times$ 5.9-6.2; tegmen length, I 2-12.5 (macropterous). 7.6 (brachypterous).

Coloration: Face (Fig. 3) brownish to black, followed by a broad testaceous band just above the antennal sockets, then a broad brownish to black band connecting the tops of the eyes and followed again by testaceous; basal half of clypeus testaceous. Antennae more or less unicolorous throughout, or with basal segments yellowish brown, the remainder darker. Pronotum and tegmina semi-hyaline to subopaque, the less transparent specimens whitish-yellow, the others testaceous. Pronotum with an irregularly shaped, arched, longitudinal, light to dark brownish band on each side of the mid-line, not reaching the borders, but converging posteriorly; surface sprinkled with a few to many brownish dots of variable size (Figs, I, 2, 5, 7). Humeral vein with a brownish stripe of variable length, the stripe solid (Fig. 5) or pale with dark lines on either side (Fig. I); right tegmen dark on the portion covered by the left tegmen (Fig. I). Tergites mostly dark, either solidly dark brown or interspersed with some pale areas, laterally with a broad testaceous or yellowish-white border, sprinkled with small brown dots; in the subopaque $\sigma^{\top}$ the seventh segment has a round brownish spot on each side (Fig. 4). Sternites dark brown with or without a lateral testaceous border 

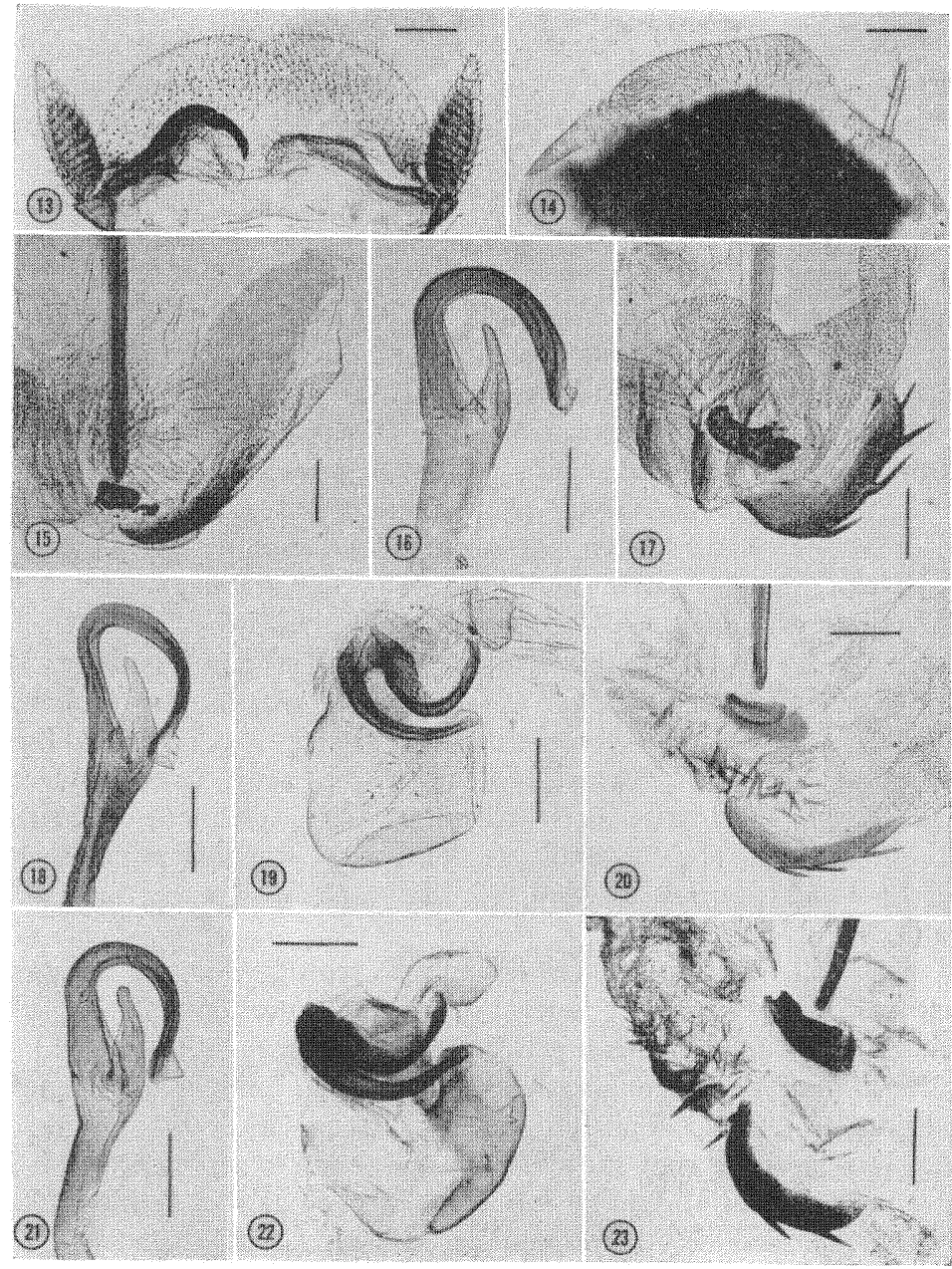

Figs. 13-23. Pinaconota bifasciata. Male structures. 13-14. Supra-anal plate (dorsal) and subgenital plate (ventral; left style missing), respectively. From male taken at Miami (with orchids from Brazil), 26 July, 1971. 15-23. Genital phallomeres: 15-16. L2vm, L2d, and prepuce (15) and R2 (16), from $\hat{o}$ shown in fig. 5. 17-19. L2d and prepuce (17), R2 (18), and L1 (19) from $\hat{\delta}$ shown in fig. 1. 20-21. L2d, and prepuce (20), and R2 (21), from $\hat{o}$ shown in fig. 7. 22-23. L1 (22), and L2d and prepuce (23), of male whose supra-anal and subgenital plates are shown in figs. 13 and 14. (scale: figs. $13-14=0.5 \mathrm{~mm}$; all others $=0.3 \mathrm{~mm}$; all figures from $\mathrm{KOH}$ cleared, flattened preparations). 
(if present, continuing around the margin of the subgenital plate). Legs testaceous with some brownish areas, especially on front femora.

9. (Figs. 6, 8, 9). Similar to male except that the subgenital plate is symmetrical and rounded.

Measurements (mm): Total length, I7-2I; pronotum length $\times$ width, 4.2-5.5 $\times$ 6.5-8.2; tegmen length, I4-16 (macropterous), 8.9 (brachypterous).

Nymphs: Nymphs are brownish, and yellowish brown, the markings differing with different instars (Figs. IO-I2). Young and older stages have the characteristic head markings of the adult. The pro-, meso-, and metanotum are sprinkled with variable sized raised dots, a row of several elongated ones along the mid-posterior border just above the margin. A similar row of elongated granules along the hind margins of the abdominal tergites, the granules decreasing in size laterally, and smaller on the posterior segments.

Material examined (All specimens from the U.S. National Museum) : $\sigma^{x}$, o nymph, $2 \sigma^{x}$ nymphs, Brazil (at San Francisco, I 7. XI. 1970, with bromeliads); + , $\sigma^{x}$ nymph, Brazil (at Hoboken, 29, 30. X. 1940, with bromeliads); $\sigma^{\top}$ and $\&$, Corupa (Hansa Humboldt), S. Cath., Brazil, XI. I944 ( + ), XI. I945 ( $\left.o^{x}\right)$ (A. Maller leg); ㅇ, Brazil; + , Brazil 20. I. 1972 (on plane at Miami, with bromeliads); $\sigma^{*}$, Brazil, 26. VII. I97I (at Miami, with orchids); brachypterous $\sigma^{x}$ and $\%$, Ilha das Alcatrazes, S. Paulo, Brazil.

I was not able to obtain Saussure's type $q$ but the available macropterous specimens in general fit his description and figure. The pronotal markings of the brachypterous specimens were of a much lighter brown than the long-winged forms and the male preputial modification differed slightly (Fig. 20) from the others (Figs. I7, 23). It is possible that more than one species is represented in the above material but additional specimens, particularly of brachypterous forms are needed before this can be decided.

Walker (1868) described the male of Panchlora inaequalis which Kirby (1904) listed under Tribonium, and which was placed in Proscratea by Princis (1958). The male genitalia of Panchlora (Roth, 1971a), Tribonium spp. (Roth, 1970) ${ }^{1}$, and Proscratea com-

\footnotetext{
${ }^{1}$ The following changes should be made in the explanation of figures in my Zetoborinae paper (Roth, 1970): p. 223, Fig. 18, Tribonium conspersum (Guérin) should be Tribonium spectrum (Eschtz.); Fig. 19 should be 20; Fig. 20 should be 19 and Tribonium sp. should be Tribonium conspersum (Guérin); page 234, shown in Fig. 19 should read 20; Tribonium conspersum should read Tribonium spectrum; p. 235, Tribonium sp. should read Tribonium conspersum and shown in Fig. 20 should read 19).
} 
planata (Perty) (Roth, 1973; type of genus, Princis, 1964), are so different from inaequalis that it is unwarranted to place this species in any of these genera. The most unusual features of the genitalia of inaequalis are the $\mathrm{R}_{2}$ (Fig. 3I) with a basal projection extending toward the inner margin of the hook, and the densely setose preputial modification (Figs. 29, 30). The R2, L2d, and $\mathrm{LI}_{\mathrm{I}}$ (Figs. 29-32) of inaequalis are remarkably similar to these structures of Pinaconota bifasciata (Figs. I5-23). The prepuce in both have a large faintly sclerotized plate which lies under the L2vm; the prepuce of inaequalis differs in lacking some large spines on the border and smaller ones on the membrane above L2vm. Although the color markings and size of Panchlora inaequalis differs from Pinaconota bifasciata (cf. Figs. I and 24), the marked similarity in their genitalia and other characters indicates that the former species should be placed in Pinaconota.

The following is a redescription of Panchlora inaequalis supplementing that of Walker.

\section{Pinaconota inaequalis (Walker), n. comb.}

(Figs. 24-32)

Panchlora inaequalis Walker (1868, 33, $\hat{\delta}$ not $q$ as indicated). Tribonium inaequalis (Walker) (Kirby, 1904, 157).

Proscratea inaequalis (Walker) (Princis, 1958, 70, ô).

$\sigma^{\pi}$ holotype (Fig. 24). Interocular space about twice the width of one eye. Prothorax widest below middle, arched anteriorly, disk flat, slanting laterally; lateral angles rounded, posterior margin slightly convex. Supra-anal plate broadly rounded with a distinct mesal invagination. Cerci reaching to about the hind margin of supraanal plate (Fig. 25). Subgenital plate asymmetrical, roughly triangular, rounded on the left side and broadly incised on the right; styles absent, but these apparently had been broken off (Fig. 26). Costa of tegmina slightly and regularly curved. Anterior margin of front femur with 5 or 6 heavy spines, more or less uniform in size, followed by about a dozen small uniformly spaced piliform setae, terminating in a large distal spine (Type B); posterior margin with I stout spine about $1 / 4$ distance from apex; distal spine present; genicular spine absent; anterior margins of mid and hind femora with 2 or 3 , and posterior margins with 3 widely spaced, small stout spines; genicular spines present as well as distal spines 


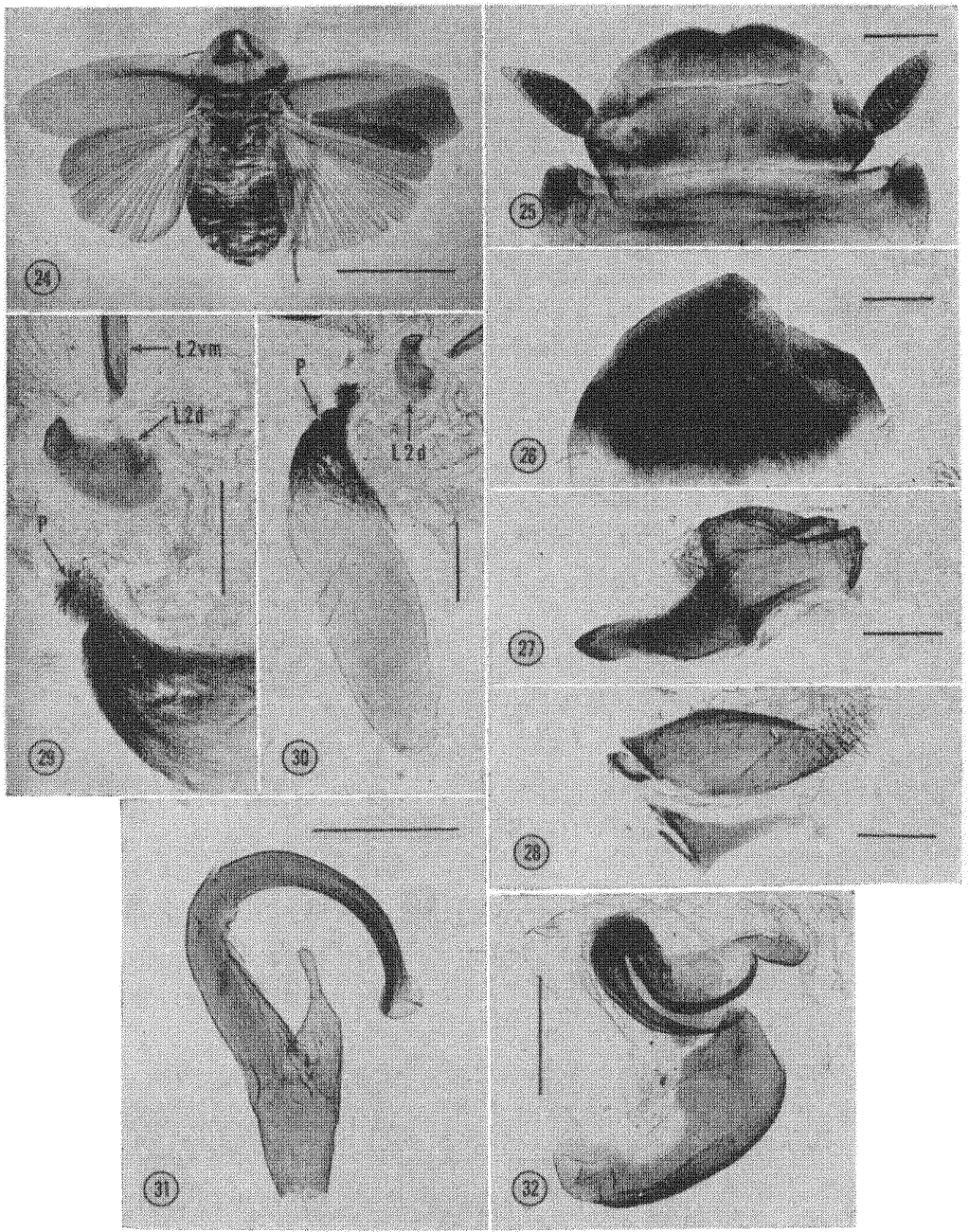

Figs. 24-32. Adult $\hat{o}$ of Pinaconota inaequalis (Walker) (holotype of Panchlora inaequalis Walker). 24. Adult. All structures shown in the following figs. are from this $\hat{o}$. 25. Supra-anal plate and cerci (dorsal). 26. Subgenital plate (ventral). 27. Right paraproct. 28. Left paraproct. 2932. Parts of the genitalia; fig. 30 shows the entire preputial modification, which is only partly shown in fig. 29 . ( $22 \mathrm{vm}=$ ventromedial sclerite (only apex is shown); L2d $=$ dorsal sclerite of second left phallomere; $\mathrm{P}=$ preputial membrane). 31. R2 (second sclerite of right phallomere). 32. L1 (first sclerite of left phallomere). (scale: fig. $24=10 \mathrm{~mm}$; figs. $25-26$ $=1 \mathrm{~mm}$; figs. 27,28 , and $32=0.5 \mathrm{~mm}$; fig. $29=0.4 \mathrm{~mm}$; figs. $25-32$ from KOH cleared, flattened preparations on 2 slides labeled $66 \mathrm{BMNH}$ ). 
on both margins of mid and hind femora. ${ }^{2}$ Tarsal claws equal, arolia and pulvilli well developed. Right and left paraprocts shown in figures 27 and 28. Genitalia as shown in figures 29-32; L2d is a flat unevenly sclerotized plate separated from L2vm (Figs. 29-30); prepuce highly modified with an area of densely packed small setae leading into a large smooth, banana-shaped (when flattened) sclerotized plate (Fig. 30). R2 with an elongated process extending upward toward the curved inner margin of the hook (Fig. 3I); LI with a curved, heavily sclerotized cleft, lower lobe lacking setae, with an unevenly broad, sclerotized marginal area (Fig. 32).

Measurements $(\mathrm{mm})$ : Overall length about $2 \mathrm{I}$; length and width of pronotum, $5.6 \times 8.6$.

Coloration: Head black. Pronotum brownish yellow, semi-hyaline; a broad black inverted Y-shaped band extends from the anterior arched border to the disk; a broad black, undulating band extends along the posterior border between the two lateral angles. Abdominal tergites and sternites piceous. Tegmina reddish tawny, costal area testaceous and corciaceous towards base, with a dark humeral line; right tegmen with a large blackish region where it is covered by the left tegmen. Wings brownish.

Material examined: Holotype $\delta^{\top}$ of Panchlora inaequalis Walker, locality unknown. From Mr. Argent's Collection. Type in British Museum (Natural History).

Shelford (1907) stated that Ischnoptera (?) obliqua Walker "appears to be undoubtedly referable to the genus Pinaconota, Sauss.; it can be distinguished from the only other species in the genus $P$. bifasciata, Sauss., by its much larger size." $P$. obliqua differs markedly from bifasciata in femoral armature, relative length of cerci, bulging eyes, and $\sigma^{\star}$ genital phallomeres. Because of the morphological differences, especially in the 3 genital phallomeres, I am placing obliqua in a new genus characterized as follows:

Gurneya n. gen. ${ }^{3}$

Type-species: Ischnoptera (?) obliqua Walker ( I869, p. I48) (present designation).

${ }^{2}$ Princis (1958) placed inaequalis in Proscratea. The femoral armament of a female of Proscratea complanata was as follows: Anterior and posterior margins of front femur unarmed except for 1 distal spine on each; genicular spine absent. Both margins of mid femur unarmed; distal spines lacking; genicular spine present. Anterior margin of hind femur unarmed; hind margin with 3 widely spaced heavy spines; distal spines absent, genicular spine present.

${ }^{8}$ The genus is named in honor of Dr. Ashley Gurney, orthopterist at the United States National Museum, who has helped me considerably in my taxonomic studies of the Blattaria. 
0. Vertex, face, and pronotum deeply punctate (Figs. 34-35). Entire ventro-anterior margin of fore femur armed with a row of small, bimarginally serrated, closely spaced spines, lacking a large distal spine (Fig. 36) ; ventro-anterior margin of mid femur similarly armed but the spines fewer and not uniformly spaced. Tarsi very short, fimbriate, unarmed beneath. Supra-anal plate rounded, entire. Cerci long, extending well beyond hind margin of supra-anal plate (Fig. 38). Subgenital plate asymmetrical, with a broad shallow incision on right side (Fig. 39). Styles equal, not extending beyond hind margin of subgenital plate (Fig. 39). Genital phallomeres; L2d absent, prepuce spiculate, otherwise unmodified (Fig. 40). R2 with a deep subapical incision which extends to about the middle of the hook (Fig. 4I); LI with the upper lobe (above the cleft) elongate and more narrow than the lower (Fig. 42).

In obliqua, the absence of an L2d and shape of the spicular surface of the prepuce (though lacking some long "silky" hairs on one side) resembles the same structure in Alphelixia (see Figs. 2I and 23, in Roth, 1973a). The hooked phallomere ( $R 2)$ resembles this structure in certain genera of Epilamprinae (e.g. Litopeltis, see Fig. 37, in Roth, 1971) and Blaberinae (e.g. Blaptica, see Fig. 57, in Roth, 1970a). The shape and sclerotization of the LI differs from that found in the other genera with similar appearing R2's.

\section{Gurneya obliqua (Walker), n. comb.}

$$
\text { (Figs. 33-42) }
$$

Ischnoptera (?) obliqua Walker (1869, 148, $\hat{o})$.

Pinaconota obliqua (Walker) (Shelford, 1907, p. 496, $\hat{o}$ ).

$\sigma^{x}$. (Fig. 33). Vertex and face (Fig. 34) deeply punctate, clypeus nearly smooth. Eyes large, bulging, their upper margins raised above the margin of the vertex, wide apart, the distance between them only slightly less than the distance between the antennal sockets (Fig. 34). Pronoium with scattered deep punctures, transversely elliptical, anterior margin almost straight, not covering vertex of head, posterior margin nearly straight, sides deflexed (Fig. 35). Tegmina with basal fourth punctate, covering the abdomen. Scutellum exposed, punctate. Supra-anal plate entire, rounded, its surface and hind margin covered with small fine setae; cerci more than twice the length of supra-anal plate (Fig. 38). Subgenital plate slightly asymmetrical, the right side weakly indented; styli about equal, short, not extending beyond hind margin of subgenital plate (Fig. 39). Legs short, front and mid tibiae shorter than their corresponding femora. Front femur: entire ventro-anterior margin armed with about 30 small, bimargin- 

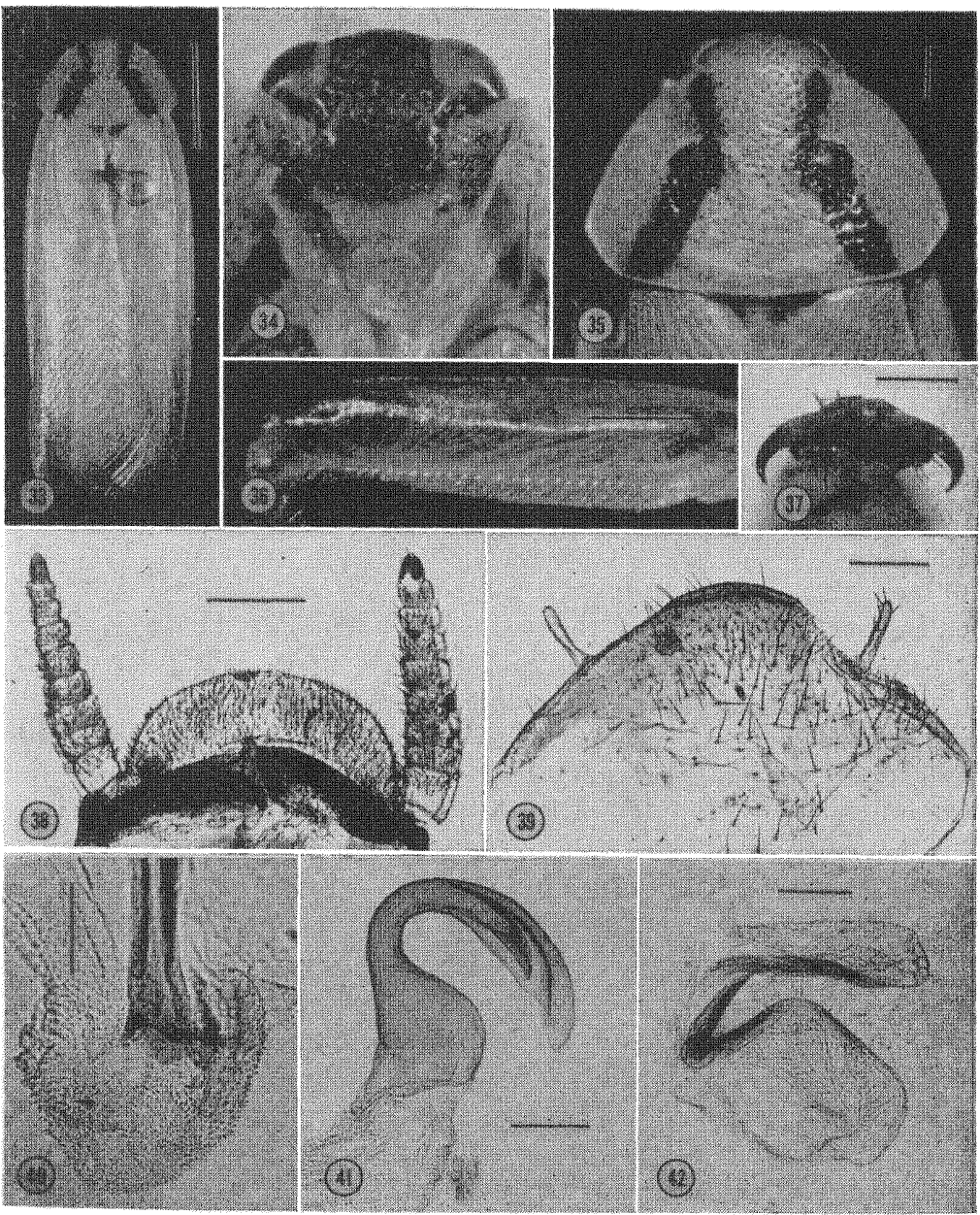

Figs. 33-42. Gurneya obliqua (Walker). Holotype ô of Ischnoptera (?) obliqua Walker. Ail structures shown in figs. $34-42$ are from the type. 33. Adult. 34. Head (frontal view). 35. Pronotum. 36. Front femur (anterior surface). 37. Tarsal claws and arolium of prothoracic leg (end view). 38. Supra-anal plate and cerci; the dark structures are paraprocts seen through the cleared tergite (dorsal). 39. Subgenital plate (ventral). 40-42. Genital phallomeres: 40. Apex of L2vm, and preputial membrane. 41. R2. 42. L1. (Specimens shown in figs. $38-42$ are $\mathrm{KOH}$ treated, cleared, flattened preparations on a slide); (scale: fig. $33=5 \mathrm{~mm}$; figs. $34-35$ $=1 \mathrm{~mm}$; figs. $36,38-39=0.5 \mathrm{~mm}$; fig. $37=0.25 \mathrm{~mm}$; fig. $40=0.1 \mathrm{~mm}$; figs. $41-42=0.2 \mathrm{~mm}$ ). 
ally serrated, close-set row of spines (Fig. 36) ; enlarged distal spine absent; posterior margin with 5 larger bimarginally serrated spines, 2 of them relatively close together basally, the others much wider apart; distal spine present; genicular spine absent. Mid femur: entire ventro-anterior margin with about I 3 bimarginally serrated spines, those on the distal third somewhat closer together than the others; distal spine obsent; posterior margin with 5 spines plus a small distal spine; genicular spine present. Hind femur: anterior ventral margin with 7 spines; enlarged distal spine absent; ventral posterior margin with 3 or 4 larger spines; distal spine absent; minute genicular spine present. Tarsi short, unarmed beneath, both tibiae and tarsi fimbriated; all metatarsi shorter than the remaining segments combined, of their respective tarsi. Tarsal claws simple, about equal or one slightly smaller (possibly broken or worn) than the other; arolia large, roughly triangular in end view (Fig. 37); pulvilli very large and, except for those on the metatarsi, cover the entire ventral surface of the segments. Genitalia shown in figures 40-42. Li with a deep sclerotized cleft; the upper lobe (above cleft) elongate, relatively narrow, roughly rectangular extending slightly beyond margin of lower lobe; lower lobe much larger than upper, and without setae (Fig. 42). L2d absent, preputial membrane spicular, unmodified (Fig. 40). R2 broadened at base, a deep subapical incision extends to about the middle of the hook (Fig. 4I).

Measurements $(\mathrm{mm})$ : Overall length, 2I ; body length, I8; tegmen length, I7; pronotum length $\times$ width, $3.9 \times 6.2$.

Coloration: Pale testaceous. Head castaneous, fuscous band between eyes; clypeus, mouthparts and antennae testaceous. Two angulate black stripes on the pronotum extend from anterior to posterior margins; anteriorly the stripes are narrow and converge; posteriorly the stripes are broader and diverge (Fig. 35). Tegmina with a short humeral castaneous stripe. Scutellum marked with castaneous. Abdomen and legs pale testaceous.

ㅇ. Unknown.

Material examined: Holotype $\sigma^{x}$ of Ischnoptera (?) obliqua Walker. Brazil. Type in Hope Department of Entomology, Oxford Museum, England.

\section{SUMMARY}

The genus Pinaconota is redescribed together with 2 species, $P$. bifasciata (Sauss.) and $P$. inaequalis (Walker). A new genus Gurneya is erected for Ischnoptera (?) obliqua Walker which Shelford had incorrectly assigned to Pinaconota. 


\section{ACKNOWLEDGEMENTS}

I thank Dr. David Ragge, British Museum (Natural History), London for the loan of the type of Panchlora inaequalis Walker, Dr. M. W. R. de V. Graham, Hope Department of Entomology, Oxford, for the loan of the type of Ischnoptera (?) obliqua Walker, Dr. Ashley Gurney, U.S. National Museum for specimens of Pinaconota bifasciata (Saussure), and Mr. Samuel Cohen for taking the photographs.

\section{REFERENCES}

KIRBY, W. F.

1904. A synonymic catalogue of Orthoptera. Vol. I. London, pp. 61205.

PRINCIS, K.

1958. Revision der Walkerschen und Kirbyschen Blattarientypen im British Museum of Natural History, London II. Opusc. Entomol. 23 : $59-75$.

1964. Orthopterorum Catalogus. Pars 6: 173-284. 's-Gravenhage.

1967. Orthopterorum Catalogus. Pars 11: 616-710. 's-Gravenhage.

ROTH, L. M.

1970. The male genitalia of Blattaria. III. Blaberidae: Zetoborinae. Psyche 77: 217-236.

1970a. The male genitalia of Blattaria. IV. Blaberidae: Blaberinae. Psyche 77: 308-342.

1971. The male genitalia of Blattaria. VII. Galiblatta, Dryadoblatta, Poroblatta, Colapteroblatta, Nauclidas, Notolampra, Litopeltis, and Cariacasia (Blaberidae: Epilamprinae). Psyche 78: 180192.

1971a. The male genitalia of Blattaria. VIII. Panchlora, Anchoblatta, Biolleya, Pelloblatta, and Achroblatta. (Blaberidae: Panchlorinae). Psyche 78: 296-305.

1973. The male genitalia of Blattaria. X. Blaberidae. Pycnoscelus, Stilpnoblatta, Proscratea (Pycnoscelinae), and Diploptera (Diplopterinae). Psyche 80: 249-264.

1973a. Brazilian cockroaches found in birds' nests, with descriptions of new genera and species (Dictyoptera: Blattaria: Blaberidae and Blattellidae). Proc. Entomol. Soc. Washington 75: 1-27.

SAussure, H. DE

1862. Orthoptera Nova Americana. Diagnoses preliminares, III series Rev. Mag. Zool. 14: 163-171.

1864. Orthoptères de L'Amérique Moyenne. Mém. Soc. Phys. et d'Hist. Nat. Genève, 279 pp.

1895. Revision de la Tribu des Panesthiens et de celle des Épilampriens. Insectes Orthoptères de la famille des Blattides. Rev. suisse Zool. 3: 299-364. 
SHELFORD, R,

1907. Studies of the Blattidae (continued). Trans. Entomol. Soc. London. Part IV.: 487-519.

1910. Genera Insectorum. Orthoptera. Fam. Blattidae. Subfam. Epilamprinae. Fasc. 101: 1-21.

WALKER, F.

1868. Catalogue of the specimens of Blattariae in the collection of the British Museum. London. 239 pp.

1869. Supplement to the Blattariae of the British Museum. London. pp. 119-156. 

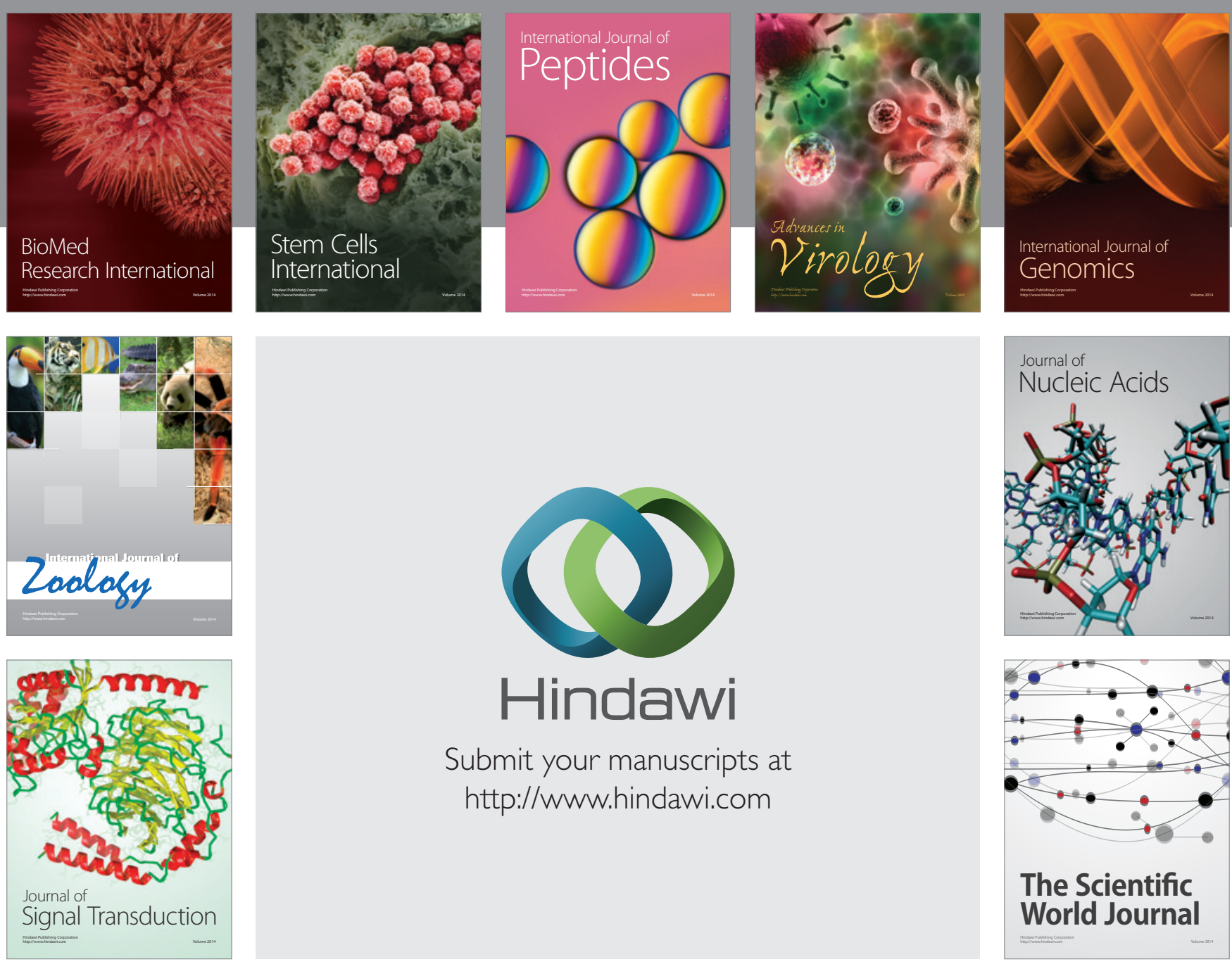

Submit your manuscripts at

http://www.hindawi.com
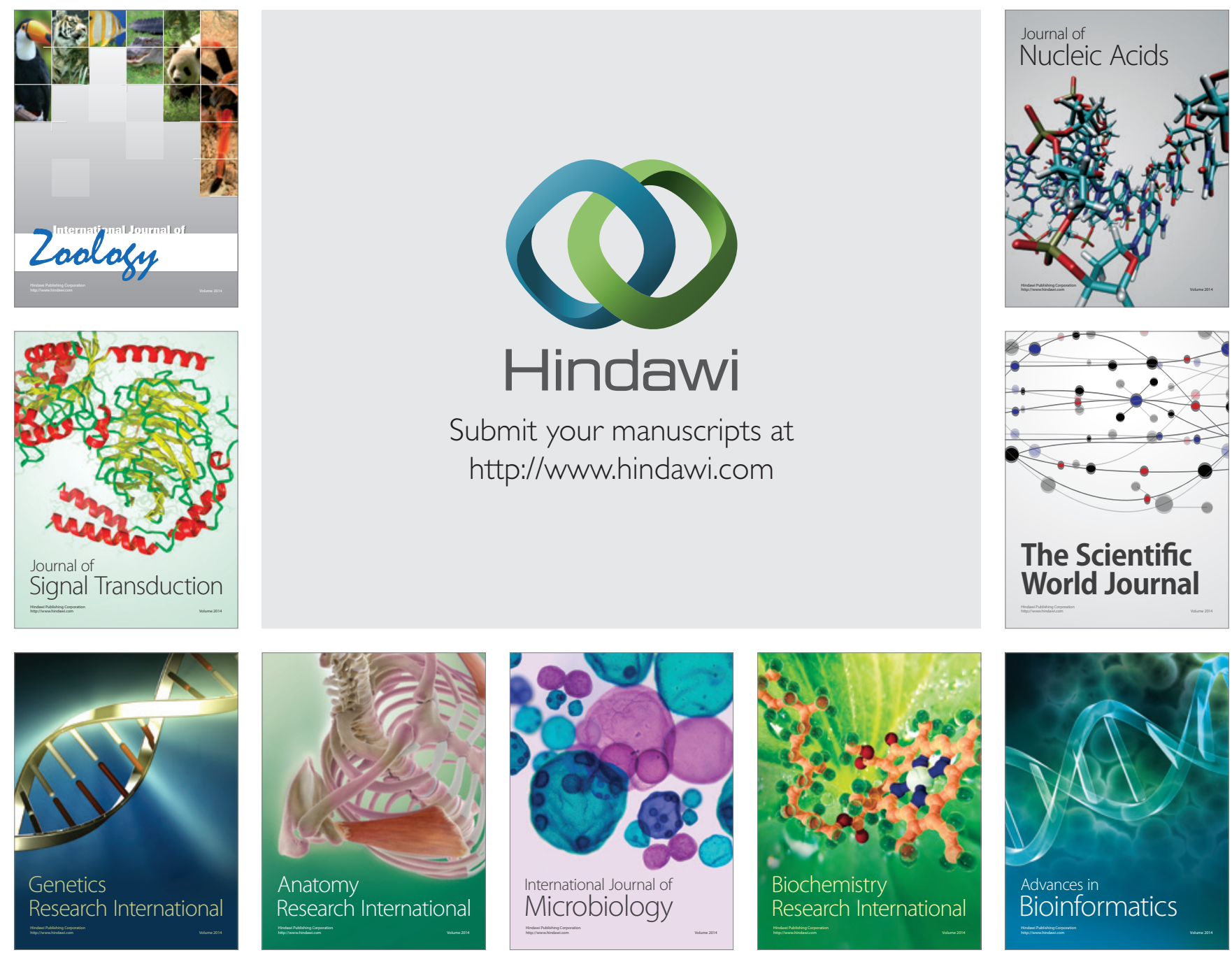

The Scientific World Journal
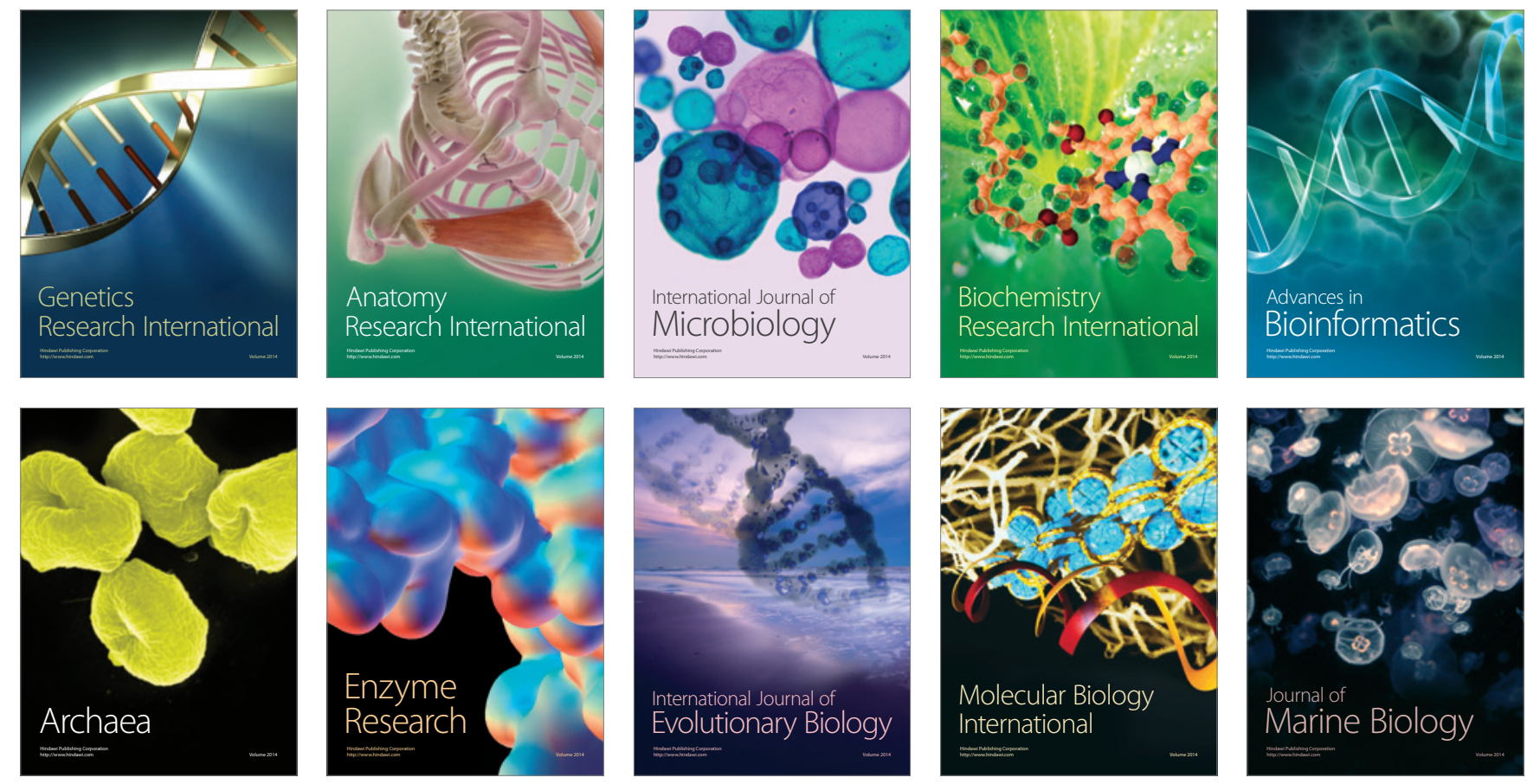